\begin{tabular}{|l|l|l||}
\hline \multicolumn{2}{|c|}{ PublisherInfo } \\
\hline \hline PublisherName & $:$ & BioMed Central \\
\hline \hline PublisherLocation & $:$ & London \\
\hline \hline PublisherImprintName & $:$ & BioMed Central \\
\hline \hline
\end{tabular}

\title{
Muscling in on chromosomal clusters
}

\begin{tabular}{|l|l|l||}
\hline \multicolumn{2}{|c|}{ ArticleInfo } \\
\hline \hline ArticleID & $:$ & 4568 \\
\hline \hline ArticleDOI & $:$ & $10.1186 /$ gb-spotlight-20020902-01 \\
\hline \hline ArticleCitationID & $:$ & spotlight-20020902-01 \\
\hline \hline ArticleSequenceNumber & $:$ & 234 \\
\hline \hline ArticleCategory & $:$ & Research news \\
\hline \hline ArticleFirstPage & $:$ & 1 \\
\hline \hline ArticleLastPage & $:$ & 2 \\
\hline \hline & & RegistrationDate : 2002-9-2 \\
\hline ArticleHistory & $:$ & OnlineDate \\
\hline \hline ArticleCopyright & $:$ & BioMed Central Ltd2002-9-2 \\
\hline \hline ArticleGrants & $:$ & \\
\hline \hline ArticleContext & $:$ & 130593311 \\
\hline \hline
\end{tabular}




\section{Jonathan B Weitzman}

Email: jonathanweitzman@hotmail.com

It is becoming increasing apparent that eukaryotic genomes are organized into regions containing clusters of co-regulated genes. In the August 29 Nature, Roy et al. describe clusters of muscleexpressing genes in the Caenorhabditis elegans genome (Nature 2002, 418:975-979). They developed a method called 'messenger RNA tagging' that uses immunoprecipitation of an epitope-tagged RNAbinding protein to purify mRNA expressed in different tissues; they then used DNA microarrays to analyse the enrichment of co-immunoprecipitated mRNAs. Roy et al. found over 1,000 genes that were consistently enriched in six muscle mRNA-tagging experiments. When they mapped the chromosomal locations of these genes, they found that almost a third of them are positioned within 10kb of another muscle-expressed gene. Many of the muscle genes are found in clusters of 2-5 genes, sometimes interrupted by a non-expressed gene. Additional analysis provided evidence for clustering of genes expressed in sperm or oocytes. Roy et al. speculate that gene clusters may represent regions of active chromatin.

\section{References}

1. Evidence for large domains of similarly expressed genes in the Drosophila genome.

2. Nature, [http://www.nature.com]

3. The Kim Lab, [http://cmgm.stanford.edu/ kimlab] 